ISSN 2078-6077.

Наукові зошити історичного факультету Львівського університету. 2018-2019. Випуск 19-20. С. 211-220 Proceedings of History Faculty of Lviv University. 2018-2019. Issue 19-20. C. 211-220

УДК 94:[341.78(44-25)ЗУНР:327(477.8)]”1919/1923”

\title{
ПРЕДСТАВНИЦТВА УРЯДУ ЗУНР У ПАРИЖІ (1919-1923)
}

\author{
Ганна-Меланія ТИЧКА \\ Львівський національний університет імені Івана Франка \\ кафедра нової та новітньої історії зарубіжних країн \\ вул. Університетська, 1, Львів, 79000, Україна \\ e-mail: zelenamush@gmail.com
}

\begin{abstract}
Представництво ЗУНР у Парижі діяло від початку 1919 р. до березня 1923 р. Впродовж цього періоду неодноразово змінювався його особовий склад, структура та офіційна політика. У 1919 р. галицькі дипломати належали до складу Надзвичайної дипломатичної місії УНР та офіційно дотримувалися соборницьких поглядів. Водночас, дехто із них намагався вести власну політику в рамках “галицького бюро”. У грудні 1919 р. відбувся розрив між УНР та ЗУНР і галичани вийшли із соборницької делегації, заснувавши Український національний комітет, який незабаром покинули. Від 1920 р. представники ЗУНР у Парижі виступали за визнання самостійности галицького регіону. Водночас, дехто із них дотримувався проросійських та навіть прорадянських поглядів, що істотно впливало на характер діяльности представництва.
\end{abstract}

Ключові слова: дипломатія, делегація, ЗУНР, Париж, Східна Галичина.

Структура та генеза західноукраїнської делегації у Франції висвітлена в історіографії недостатньо. У більшості наукових праць діяльність галицьких дипломатів у Парижі не є головним об'єктом дослідження, а розглядається винятково в контексті взаємодії українців із союзницькими політиками в рамках Паризької мирної конференції (далі - ПМК), що не дозволяє комплексно осмислити зазначену проблематику ${ }^{1}$. Ця студія покликана виправити ситуацію та започаткувати грунтовне вивчення діяльности делегації ЗУНР у Парижі, із дослідження якої варто розпочинати будь-які праці із зовнішньої політики Української держави галичан.

Усвідомлюючи необхідність налагодити дипломатичні взаємини із країнами Антанти у переддень мирного конгресу, галицька Українська Національна Рада (далі - УНРада) ще 22 грудня 1918 р. делегувала до Парижа власну дипломатичну місію, до складу якої увійшли Василь Панейко, Євген Левицький та Антон

${ }^{1}$ Михайло Лозинський, Галичина в рp. 1918-1920, (Ню Йорк: Червона калина, 1970); Ilko Borshchak, L'Ukraine à la Conférence de la paix, 1919-1923, (Dijon, 1938); Матвій Стахів, Західня Украӥна. Нарис історії державного будівництва та збройної боротьби і дипломатичної оборони в 1918-1923, Т. 4-6. (Скрентон: 3 Друкарні Народної Волі, 1958-1961); Микола Литвин, Украйнсько-польська війна 1918-1919pр., (Львів: Інститут українознавства ім. І. Крип’якевича НАНУ: Інститут Центрально-Східної Свропи, 1998); Ігор Дацків, “Діяльність дипломатичної делегації ЗУНР на Паризькій мирній конференції 1919 року”, Науковий вісник Дипломатичної академії України, Вип. 19, (2012): 227-239.

${ }^{2}$ Тишкевич Михайло (1857-1930), граф, дипломат і політичний діяч УНР, публіцист, історик, меценат, Центральний державний історичний архів України, м. Львів ( далі - ЦДІАЛ), ф. 681, оп. 1 , спр. 1 , арк. 1 . 
ISSN 2078-6077. Наукові зошити історичного факультету Львівського університету. 2018-2019. Випуск 19-20. Proceedings of History Faculty of Lviv University. 2018-2019. Issue 19-20.

Петрушевич ${ }^{2}$. Один із них, А. Петрушевич, так описував подальшу долю того представництва: “Ми прилучились до нього [Г. Сидоренка, делегата УНР до Парижу $-\Gamma$. T.] і спільно вибрались в дорогу. Одначе з техничних зовнішних причин, по боренню численних перепон, лише п. Сидоренкові і мені вдалося добитися до Парижу, а саме дня 20/1 1919 р. Позаяк в тім часі Галичина приєдналася до України, п. Сидоренко призначив мене секретарем Делегації [Надзвичайної місії УНР у Франції - Г. T.]”’3. Окрім А. Петрушевича, до складу представництва УНР увійшов В. Панейко, Державний секретар закордонних справ ЗУНР, який зайняв посаду товариша голови місії4. Йому, однак, вдалося прибути до французької столиці щойно у квітні 1919 р. разом з іншими членами делегації УНР, яким французьке посольство у Швайцарії тривалий час відмовляло у видачі віз. Третій делегат УНРади, Є. Левицький, так і не приїхав до Парижа і не брав участи у діяльності галицького представництва у Франції. Натомість від 1 березня 1919 р. делегація УНР прийняла на посаду радника іншого відомого галичанина, С. Томашівського. Усі вони: А. Петрушевич, В. Панейко та С. Томашівський, - працювали у делегації УНР до грудня 1919 р.

Окрім того, у квітні 1919 р. до Парижа прибула спеціяльна місія для укладення українсько-польського перемир'я у Східній Галичині, до якої входили Дмитро Вітовський, Михайло Лозинський, Олександр Кульчицький (секретар) і Альфонс Ерлє (радник Д. Вітовського) ${ }^{5}$. Д. Вітовський, як відомо, загинув в авіакатастрофі 2 серпня, повертаючись до України з Парижа ${ }^{6}$. Від липня 1919 p. в документах делегації УНР немає згадок також про А. Ерлє, тож, мабуть, він покинув місію одразу після смерти Д. Вітовського. Водночас, М. Лозинський та О. Кульчицький залишалися у делегації до грудня 1919 р.

На початку літа 1919 р. внаслідок певних дипломатичних та політичних помилок, допущених, в тому числі, з вини Г. Сидоренка, українська місія, фактично, опинилася в міжнародній ізоляції: більшість чужоземних представників уникали співпраці із нею. Водночас, на ПМК відбувалися дуже важливі події, що стали доленосними для Східної Галичини. За таких обставин представники ЗУНР В. Панейко та С. Томашівський вирішили діяти на власну руку і створили "Галицьке бюро" - організацію, яка таємно від решти українських делегатів

\footnotetext{
${ }^{3}$ Тишкевич Михайло (1857-1930), граф, дипломат і політичний діяч УНР, публіцист, історик, меценат, ЦДІАЛ, ф. 681, оп. 1, спр. 1, арк. 1.

${ }^{4}$ Вісник Державних законів УНР, [...] переписка з Директорією, Міністерством закордонних справ і Державним секретаріятом УНР, Українська Бібліотека ім. Симона Петлюри в Парижі, ф. 4 , т. 1 , док. ч. 158.

${ }^{5}$ Михайло Лозинський, Галичина в рp. 1918-1920, (Ню Йорк: Червона калина, 1970), 115; Михайло Рудницький, “Париж 1919. Переважне становище української делегації на Мирову Конференцію", Дипломатія УНР в документах та спогадах сучасників: у двох томах, упоряд. і передм. І. М. Гнатишина та ін., (Київ: Український письменник, 2008.): 269-270.

${ }^{6}$ Павло Гай-Нижник, “Дмитро Вітовський: встановлення історичної дати та обставин загибелі”, Військово-історичний альманах, № 1, (2010): 47-54.
} 
намагалася діяти у Парижі від імени ЗУНР 7 . У дипломатичних нотах, які вони розсилали чужоземним делегаціям, проголошувалися зовсім інші вимоги, аніж ті, які декларувала делегація УНР. Про діяльність "Галицького бюро" науці досі відомо дуже мало. У різних джерелах вказуються різні дати заснування цієї інституції, немає також чіткої інформації про те, коли вона припинила своє існування, і навіть іiі назва $є$ лише умовною. Із окремих документів довідуємося, що осідок "Галицького бюро" був у Парижі при вулиці Віктора Гюго, що в 16-ому окрузі період після Першої світової війни ця частина міста була однією із найфешенебельніших у Парижі ${ }^{9}$, тож, безсумнівно, представники Галичини потребували значних коштів на оренду офісного приміщення. Джерело їхнього фінансування, на жаль, також залишається невідоме.

Коли про створення "Галицького бюро" стало відомо, то, як писав член місії УНР Сергій Шелухин, “між самими галичанами вийшло таке, що Панейко од М. [Михайла Лозинського? - Г. Т.] тікав і сховався за стіл, бо той кинувся на його бити. Покійник Вітовський кинувся бити Томашівського, та я схопив його за руки"10. Врешті, орієнтовно наприкінці серпня 1919 р. діяльність "Галицького бюро" була припинена, а заколотники повернулися до роботи в місії УНР ${ }^{11}$, однак, як писав М. Лозинський, “Між Панейком і Томашівським і Делегацією запанував повний розрив" 12 .

Відтак, 16 грудня 1919 р. майже всі представники ЗУНР вийшли зі складу делегації УНР, мотивуючи свій вчинок тим, що 2 грудня уряд УНР уклав із Польщею договір про взаємне визнання кордонів, які, згідно $з$ цим договором, проходили по р. Збруч. ${ }^{13}$ Тим часом, члени місії, які представляли УНР, оголосили, що вони виганяють 3 місії делегатів ЗУНР, бо УГА перейшла на бік армії Антона Денікіна ${ }^{14}$. Як би там не було, галичани вийшли зі складу делегації і створили Український Національний Комітет (далі - УНК). ${ }^{15}$

\footnotetext{
${ }^{7}$ Копії документів на французькій мові делегації української республіки в Парижі (19191920 рр.), Центральний державний архів вищих органів влади та управління України (далі ЦДАВО), ф. 3603, оп. 1, спр. 6, арк. 53-54.

8 Листування Президента Української національної ради $[\ldots]$ про міжнародне визнання i захист суверенітету ЗУНР, засудження польської політики в Західній Україні та з інших питань (1 серпня 1920 - 28 грудня 1920), Центральний державний архів громадських об'єднань України (далі - ЦДАГО), ф. 269, оп. 1, спр. 61, арк. 91.

${ }^{9}$ Cyril Grange, "Les classes privilégiées dans l'espace parisien (1903-1987)", Espace, Populations, Sociétés, № 1 (1993): 14-15.

${ }^{10}$ Євген Чикаленко, Щоденник 1919-1920, за ред. В. Верстюка та М. Антоновича, (Київ; Нью-Йорк: Видавництво ім. О. Теліги, 2005), 337.

${ }^{11}$ Копії документів на французькій мові делегації української республіки в Парижі (19191920 рр.), ЦДАВО, ф. 3603, оп. 1, спр. 6, арк. 53-54.

${ }^{12}$ Михайло Лозинський, Галичина в рр. 1918-1920, (Ню Йорк: Червона калина, 1970), 118.

13 “Важні переміни в Парижі”, Український прапор, ч. 38, (1919): 2.

${ }^{14}$ Євген Чикаленко, Щоденник 1919-1920, за ред. В. Верстюка та М. Антоновича, (Київ; Нью-Йорк: Видавництво ім. О. Теліги, 2005), 337.

${ }^{15}$ Протоколи засідання з'їзду закордонних членів партій соціалістів-федералістів [...] та інформаційні відомості від посольства в Парижі про діяльність національного українського комітету в Парижі [...], ЦДАВО, ф. 3696, оп. 2, спр. 332, арк. 2.
} 
ISSN 2078-6077. Наукові зошити історичного факультету Львівського університету. 2018-2019. Випуск 19-20. Proceedings of History Faculty of Lviv University. 2018-2019. Issue 19-20.

До складу УНК увійшли практично всі делегати ЗУНР, які станом на грудень 1919 р. працювали в місії УНР, зокрема: В. Панейко, С. Томашівський, А. Петрушевич та О. Кульчицький ${ }^{16}$. М. Лозинський, на противагу решті “галицьких сепаратистів”, вважав, що необхідно за всяку ціну зберігати єдність України “для того, щоби спільно впасти і полишити тим, що далі будуть вести боротьбу за українську державність, ясну історичну традицію"17. Зважаючи на це, він принципово відмовився від участи в УНК, а, згодом, і від співпраці 3 делегацією Західної України у Парижі.

У декларації УНК від 19 грудня 1919 р. проголошено, що ця організація “бере на себе тимчасово захищення національних інтересів України перед міжнародним політичним світом", поки "не буде сформовано нову правильну репрезентацію України"18. Як бачимо, УНК претендував на статус всеукраїнського представництва в Парижі, тож його засновники намагалися залучити до організації не лише галичан, але й наддніпрянців. Однак, більшість представників Великої України, які приєдналися до УНК, були дрібними чиновниками колишнього гетьманського уряду і не мали реальних політичних впливів. Серед них варто виокремити хіба що Сергія Моркотуна, колишнього особистого секретаря Павла Скоропадського, тісно пов'язаного з масонським рухом та проросійськими середовищами у Парижі. Саме він очолив УНК після виходу з його складу представників уряду ЗУНР і довгий час залишався чи не єдиним активним представником цієї організації у французькій столиці.

У січні 1920 р. галицькі делегати покинули УНК. Дослідник А. Іванець припускав, що причиною цього стала поразка військ А. Денікіна у боях під Новоросійськом на початку січня 1920 р. ${ }^{19}$., яка знизила популярність проросійських орієнтацій угалицьких політичних колах. Згідно з іншими джерелами, представники ЗУНР перебували у складі УНК до кінця травня 1919 p. ${ }^{20}$

Як би там не було, після виходу із УНК галичани продовжили свою діяльність у рамках Делегації Західної України (Галичини) $)^{21}$, відомої також як “Делєгація Західно-Української Народної Республіки”22. Згідно 3 твердженням М. Лозинського, вона була заснована одразу після виходу представників ЗУНР

${ }^{16}$ Андрій Іванець, “До питання про діяльність паризького Українського національного комітету (1919-1921рр.)”, Украӥнський історичний журнал, № 5, (2010): 120.

${ }^{17}$ Михайло Лозинський, Галичина в рр. 1918-1920, (Ню Йорк: Червона калина, 1970), 180.

${ }^{18}$ Там само, 206.

19 Андрій Іванець, “До питання про діяльність паризького Українського національного комітету (1919-1921рр.)”, Украӥнський історичний журнал, № 5, (2010): 120.

${ }^{20}$ Листування делегації УНР в Парижі з Міністерством закордонних справ УНР по міжнародні відносини, доповіді представників делегації про роботу, огляди французької преси про українське питання тощо, ЦДАВО, ф. 3603, оп. 1, спр. 8, арк. 19.

${ }^{21}$ Листування Президента Української національної ради [...] про міжнародне визнання i захист суверенітету ЗУНР, засудження польської політики в Західній Україні та з інших питань (1 серпня 1920 - 28 грудня 1920), ЦДАГО, ф. 269, оп. 1, спр. 61, арк. 72 зв.

${ }^{22}$ Михайло Лозинський, Галичина в рр. 1918-1920, (Ню Йорк: Червона калина, 1970), 118. 
зі складу місії УНР у грудні 1919 р. ${ }^{23}$, а, отже, певний час діяла паралельно $з$ УНК. Принагідно варто зазначити, що офіси цих організацій у першій половині 1920 р. знаходилися по сусідству: УНК - при вулиці Анрі Мартена під номером 5 bis $^{24}$, а делегація ЗУНР - на тій же вулиці у будинку № $15^{25}$.

Крайньою датою існування галицького представництва у Парижі можна вважати 14 березня 1923 р., коли Рада Амбасадорів ухвалила приєднати Східну Галичину до Польщі. Як стверджував присутні на той час у Парижі український дипломат Йосафат Жан, галицькі делегати повернулися до Відня наступного ж дня після цієї події ${ }^{26}$.

Від грудня 1919 р. до травня 1920 р. делегацію очолював В. Панейко. Після його звільнення, спричиненого, начебто, відмовою $Є$. Петрушевича від проросійської орієнтації, тимчасовим головою галицького представництва у Франції став С. Томашівський ${ }^{27} .20$ січня 1921 р. за наказом Є. Петрушевича С. Томашівського звільнено, а на його місце призначено Степана Витвицького, який залишався на цій посаді до кінця існування делегації ${ }^{2}$.

Штат представництва Західної України у Парижі був незначний. На початку 1920 р. до делегації ЗУНР належали: В. Панейко, С. Томашівський, А. Петрушевич та О. Кульчицький ${ }^{29}$. I В. Панейко, і С. Томашівський, покидаючи посаду голови делегації, одночасно припиняли також своє членство у ній. Отже, на початку 1921 р. до складу представництва ЗУНР входили С. Витвицький, А. Петрушевич та О. Кульчицький. Двоє 3 них, А. Петрушевич та О. Кульчицький, були незмінними секретарями делегації, аж поки у червні 1922 р. О. Кульчицький не був звільнений ${ }^{30}$. У листі до Є. Петрушевича він пояснював, що хотів підшукати собі нову роботу, бо думав, що делегація найближчим часом закриється, але С. Витвицький, довідавшись про це, неправильно його зрозумів, розгнівався і звільнив із займаної посади ${ }^{31}$.

${ }^{23}$ Михайло Лозинський, Галичина в рр. 1918-1920, (Ню Йорк: Червона калина, 1970), 118.

24 Листування Президента Української національної ради [...] про міжнародне визнання $\mathrm{i}$ захист суверенітету ЗУНР, засудження польської політики в Західній Україні та з інших питань (14 січня 1920 - 30 липня 1920), ЦДАГО, ф. 269, оп. 1, спр. 60, арк. 146.

25 Листування Президента Української національної ради [...] про міжнародне визнання i захист суверенітету ЗУНР, засудження польської політики в Західній Україні та з інших питань (1 серпня 1920 - 28 грудня 1920), ЦДАГО, ф. 269, оп. 1, спр. 61, арк. 18.

${ }_{26}$ Йосафат Жан, Моє служіння Украӥні (Автобіографічні спомини), ксерокопія, приватний архів др. Петра Шкраб'юка, 214.Там само, 214

27 Листування Президента Української національної ради $[\ldots]$ про міжнародне визнання і захист суверенітету ЗУНР, засудження польської політики в Західній Україні та з інших питань (14 січня 1920 - 30 липня 1920), ЦДАГО, ф. 269, оп. 1, спр. 60, арк. 80.

28 Листування Президента Української національної ради [...] про міжнародне визнання і захист суверенітету ЗУНР, засудження польської політики в Західній Україні та з інших питань (1 січня 1921 - 21 грудня 1921), ЦДАГО, ф. 269, оп. 1, спр. 62, арк. 18-18зв.

${ }^{29}$ Михайло Лозинський, Галичина в рр. 1918-1920. (Ню Йорк: Червона калина, 1970), 118

30 Листування Президента Української національної ради [...] про міжнародне визнання і захист суверенітету ЗУНР, засудження польської політики в Західній Україні та з інших питань (1 січня 1921 - 21 грудня 1921), ЦДАГО, ф. 269, оп. 1, спр. 62, арк. 108.

${ }^{31}$ Там само, арк $107-108$. 
ISSN 2078-6077. Наукові зошити історичного факультету Львівського університету. 2018-2019. Випуск 19-20. Proceedings of History Faculty of Lviv University. 2018-2019. Issue 19-20.

Крім названих вище осіб, восени 1922 р. у галицькій делегації працювали Григорій Микитей та Лев Петрушевич ${ }^{32}$. Також у дипломатичній діяльності у Франції в різний час брали участь такі представники ЗУНР, як Свген Петрушевич ${ }^{33}$, Кость Левицький ${ }^{34}$, митрополит Андрей Шептицький ${ }^{35}$, а також священики Йосафат Жан ${ }^{36}$ та Франц-Ксаверій Бонн ${ }^{37}$.

Офіційна позиція західноукраїнських делегатів щодо майбутнього статусу Східної Галичини еволюціонувала під впливом політики українських урядів та подій на міжнародній арені. Так, упродовж 1919 р. галицькі представники входили до складу Надзвичайної дипломатичної місії УНР у Парижі, що передбачало їхню згоду з концепцією соборної України, до якої мали б увійти території української держави галичан. Однак, зважаючи на несприятливу для українців ситуацію на фронті та відсутність прихильности з боку Антанти, представники ЗУНР швидко дійшли висновку, що соборна Україна як проєкт на той час $\epsilon$ нежиттєздатна. М. Лозинський згадував, що наприкінці червня 1919 р. “член делєгації одної з антантських держав, який має голос в сій справі” запевняв В. Панейка, що нейтралізація галицького регіону під протекторатом Антанти $\epsilon$ значно реальніша, ніж визнання Союзниками українського галицького уряду, та обіцяв галичанам свою підтримку ${ }^{38}$. Можливо, саме ці та схожі ідеї спонукали В. Панейка і С. Томашівського утворити “галицьке бюро” та діяти на власну руку. I хоча обіцянки чужоземного дипломата не збулися, і Східну Галичину віддали під польську окупацію, ідея нейтралізації регіону ще довгий час мала своїх прихильників серед галицького політикуму.

Після виходу зі складу місії УНР у Парижі галицькі делегати відмовилися від соборницької концепції та надалі послідовно виступали за створення незалежної української держави у Східній Галичині. Цей постулат був чітко прописаний у датованому 1921 р. проєкті конституції під назвою “Основи

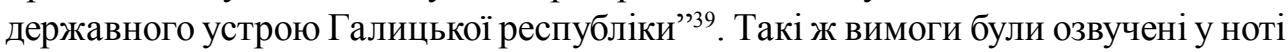

32 Листування Президента Української національної ради $[. .$.$] про міжнародне визнання i$ захист суверенітету ЗУНР, засудження польської політики в Західній Україні та з інших (14 лютого 1922 - 30 грудня 1922), ЦДАГО, ф. 269, оп. 1, спр. 63, арк. 143.

${ }_{33}$ Олег Павлишин, Свген Петрушевич (1863-1940): ілюстрований біографічний нарис, (Львів: Манускрипт-Львів, 2013), 237 - 265.

${ }^{34}$ Листування Президента Української національної ради [...] про міжнародне визнання і захист суверенітету ЗУНР, засудження польської політики в Західній Україні та з інших (14 лютого 1922 - 30 грудня 1922), ЦДАГО, ф. 269, оп. 1, спр. 63, арк. 35-42.

${ }^{35}$ Олег Сгрешій, "Греко-католицьке духівництво в умовах ЗУНР: роль у формуванні органів влади, творенні українського війська" Украӥна: культурна спадщина, національна свідомість, державність: Збірник наукових праџь, Вип. 18, (2009.), 206.

${ }^{36}$ Йосафат Жан, Моє служіння Україні (Автобіографічні спомини), ксерокопія, приватний архів др. Петра Шкраб'юка, $106-214$.

${ }^{37}$ Полеві духовники Української Галицької Армії: у 45-річчя участи у визвольних змаганнях: (матеріяли до історії), видав Іван Лебедович, (Вінніпег: Видав о. І. Лебедович, 1963), 209.

${ }^{38}$ Михайло Лозинський, Галичина в рр. 1918-1920, (Ню Йорк : Червона калина, 1970), 142.

39 Христина Машталір, “Державно-правові погляди Євгена Петрушевича” Jurnalul juridic național: teorie şi practică № 2, (2015), 16. 
галицької делегації до Ліги Націй, опублікованій в “Українському Прапорі” за 4 грудня $1920 \mathrm{p.}{ }^{40}$. Той документ, однак, прохав, щоб “до часу вирішення політичного становища Східної Галичини Високий Союз Народів [...] взяв в оборону український нарід $[\ldots]^{\prime 411}$, тобто, фактично, вимагав тимчасово передати регіон під протекторат Ліги Націй.

Окремої згадки вартують також особисті переконання окремих членів галицького представництва, які нерідко мали поважний вплив на діяльність цілої делегації. Так, С. Томашівський висував концепцію створення “нейтральної держави з західних українських земель, держави, яка би творила буфер між Польщею а Росією"42. Зважаючи на те, що польсько-російський кордон простягався на північ і південь далеко за межі Східної Галичини, С. Томашівський планував приєднати до західноукраїнської держави також Холмщину, Волинь $\mathrm{i}$ Поділля аж до Кам'янця-Подільського і навіть Закарпаття ${ }^{43}$. Водночас, у діяльності західноукраїнських представників у Парижі чітко простежувався також проросійський ухил, який підтримував, зокрема, В. Панейко, а згодом серед галицьких політиків набрали популярности прорадянські погляди. “Єсли б большевицька окупація не дала нам нічого більше як лиш знищення польської буржуазії і поділ землі між селян - то се є такий національний здобуток, якого ми б і за десятки літ самі не осягнули, " $" 44$ - писав у серпні 1920 р. А. Петрушевич, підкреслюючи, що “одинокий ратунок для нас - злука 3 большевиками 3 застереженням автономії"45.

Отже, за час свого існування від 1919 до 1923 р. галицьке представництво у Парижі еволюціонувало від сегменту Надзвичайної дипломатичної місії УНР та "галицького бюро" до Українського Національного Комітету і Делегації Західної України (Галичини). Змінювався не лише формат представництва та його особовий склад, але й офіційні погляди: у різний час галицькі дипломати виступали за злуку Східної Галичини зі соборною Україною, за нейтралізацію регіону та визнання його самостійности. Водночас, дехто із галицьких дипломатів дотримувався проросійських та прорадянських поглядів, що істотно впливало на характер діяльности представництва.

40 “Нота Делєгації Східної Галичини до Союзу Народів”, Украӥнський Прапор, .ч. 61 (1920), 1.

${ }^{41}$ Там само, 1.

42Листування Президента Української національної ради [...] про міжнародне визнання i захист суверенітету ЗУНР, засудження польської політики в Західній Україні та з інших питань (1 серпня 1920 - 28 грудня 1920), ЦДАГО, ф. 269, оп. 1, спр. 61, арк. 2 зв. - 4.

${ }^{43}$ Там само, арк. 2 зв. - 4;Листування Президента Української національної ради [...] про міжнародне визнання і захист суверенітету ЗУНР, засудження польської політики в Західній Україні та з інших питань (14 січня 1920 - 30 липня 1920), ЦДАГО, ф. 269, оп. 1, спр. 60, арк. 109.

44 Листування Президента Української національної ради $[\ldots]$ про міжнародне визнання $\mathrm{i}$ захист суверенітету ЗУНР, засудження польської політики в Західній Україні та з інших питань (1 серпня 1920 - 28 грудня 1920), ЦДАГО, ф. 269, оп. 1, спр. 61, арк. 72.

${ }^{45}$ Там само, арк. 9. 
ISSN 2078-6077. Наукові зошити історичного факультету Львівського університету. 2018-2019. Випуск 19-20. Proceedings of History Faculty of Lviv University. 2018-2019. Issue 19-20.

\title{
THE REPRESENTATIONS OF THE WEST UKRAINIAN PEOPLE'S REPUBLIC GOVERNMENT IN PARIS (1919-1923)
}

\author{
Hanna-Melanija TYCHKA \\ Ivan Franko National University of Lviv, \\ Department of Modern and Contemporary History of Foreign Countries \\ 1 Universytetska str., Lviv, 79000, Ukraine \\ e-mail: zelenamush@gmail.com
}

The article shows the history of representations of the West Ukrainian People's Republic in France in 1919-1923, its main stages of evolution, and to investigate the official position of the Galician delegates in the case of the Eastern Galicia in the various periods of its functioning.

At the beginning of 1919, the Ukrainian People's Republic and Western Ukrainian People's Republic were united, so Galician delegates became part of the Ukrainaian extraordinary diplomatic mission to Paris. The first of them, Anton Petrushevych, arrived in France in January 1919. In April, Vasyl Panyeko arrived in Paris and as well as members of the delegation for the conclusion of the UkrainianPolish armistice (Dmytro Vitovskyi, Mykhailo Lozynskyi, Alfons Erle and Oleksandr Kulchytskyi). Within the Ukrainaian extraordinary diplomatic mission to Paris, the Galicians advocated the creation of a united Ukrainian state, which would include Eastern Galicia.

In June, some of the Galicians started their own political game. Vasyl Paneyko and Stepan Tomashivsky founded a secret Galician bureau. They did not believe in the possibility of creating a Ukrainian state of Eastern Galicia and Dnieper Ukraine. They sought to create a separate Galician state. However, their conspiracy was uncovered and the rebels returned to work in the delegation of the Ukrainian People's Republic.

In December 1919, all the representatives of the West Ukrainian People's Republic, besides Mykhailo Lozynskyi, left the delegation of the Ukrainian People's Republic in Paris. Together with the former officials of the hetman's governement, they created a Ukrainian national committee, an organization that claimed to be the new legitimate delegation of Ukraine in Paris. The committee adhered to proRussian views.

In the first half of 1920 Galicians left the Ukrainian National Committee and continued their work within the Delegation of Western Ukraine (Galicia), which continued its activities until March 14, 1923. At different times, the Delegation of Western Ukraine was headed by Vasyl Panyeko, Stepan Tomashivskyi and Stepan Vytvytsky. During this period, delegates of the Galician government made a claim to create an independent Ukrainian state on the territory of Eastern Galicia.

The author focuses on the personal political views of Galician diplomats which have had a significant impact on their representation in Paris. Pro-Russian and pro-Soviet sentiments have gained popularity among Galician diplomats, whose main impacts were Vasyl Paneyko and Anton Petrushevich. Stepan Tomashivsky proposed the formation of a Galician state with the inclusion not only of Eastern Galicia but also of adjacent territories. This state should become an outpost of Europe against the Bolshevik offensive.

Thus, during its existence from 1919 to 1923, the Galician representation in Paris evolved from the segment of the Extraordinary Diplomatic Missions of the Ukrainian People's Republic and the Galician Bureau to the Ukrainian National Committee and the Delegation of Western Ukraine (Galicia). Not only the format of the representation and its personnel, but also its official views varied. At different times, the Galician diplomats advocated the inclusion of Eastern Galicia in the united Ukrainian state, the neutralization of the region and recognition of its independence. At the same time, some of the Galician diplomats followed pro-Russian and pro-Soviet views, which significantly influenced the nature of the representation.

Keywords: diplomacy, delegation, West Ukrainian People's Republic, Paris, Eastern Galicia. 


\section{REFERENCES}

Andrii Ivanets, "Do pytannia pro diialnist paryzkoho Ukrainskoho natsionalnoho komitetu (1919-1921 rr.)", Ukrainskyi istorychnyi zhurnal, No. 5, (2010).

Cyril Grange, "Les classes privilégiées dans l'espace parisien (1903-1987)", Espace, Populations, Sociétés, No. 1,(1993).

Ievhen Chykalenko, Shchodennyk 1919-1920, za redaktsiieiu V. Verstiuka ta M Antonovycha, (Kyiv; Niu-York: Vydavnytstvo im. O. Telihy, 2005).

Ihor Datskiv, "Diialnist dyplomatychnoi delehatsii ZUNR na Paryzkii myrnii konferentsii 1919 roku”, Naukovyi visnyk Dyplomatychnoi akademii Ukrainy, Vypusk 19, (2012).

Ilko Borshchak, L'Ukraine à la conférence de la paix, 1919-1923, (Dijon, 1938).

Iosafat Zhan, Moie sluzhinnia Ukraini (Avtobiohrafichni spomyny), Kserokopiia, pryvatnyi arkhiv dr. Petra Shkrabiuka.

Khrystyna Mashtalir, "Derzhavno-pravovi pohliady Yevhena Petrushevycha", Jurnalul juridic național: teorie şi practică, No. 2, (2015).

Kopii dokumentiv na frantsuzkii movi delehatsii ukrainskoi respubliky v Paryzhi (1919-1920 rr.), Tsentralnyi derzhavnyi arkhiv vyshchykh orhaniv vlady ta upravlinnia Ukrainy, f. 3603, op. 1, spr. 6.

Lystuvannia delehatsii Ukrainskoi Narodnoi Respubliky v Paryzhi z Ministerstvom zakordonnykh sprav Ukrainskoi Narodnoi Respubliky po mizhnarodni vidnosyny, dopovidi predstavnykiv delehatsii pro robotu, ohliady frantsuzkoi presy pro ukrainske pytannia toshcho, Tsentralnyi derzhavnyi arkhiv vyshchykh orhaniv vlady ta upravlinnia Ukrainy, f. 3603 , op. 1 , spr. 8 .

Lystuvannia Prezydenta Ukrainskoi natsionalnoi rady [...] pro mizhnarodne vyznannia i zakhyst suverenitetu Zakhidnoukrainskoi Narodnoi Respubliky, zasudzhennia polskoi polityky v Zakhidnii Ukraini ta z inshykh pytan (14 sichnia 1920 - 30 lypnia 1920), Tsentralnyi derzhavnyi arkhiv hromadskykh obiednan Ukrainy, f. 269, op. 1, spr. 60.

Lystuvannia Prezydenta Ukrainskoi natsionalnoi rady [...] pro mizhnarodne vyznannia i zakhyst suverenitetu Zakhidnoukrainskoi Narodnoi Respubliky, zasudzhennia polskoi polityky v Zakhidnii Ukraini ta z inshykh pytan (1 serpnia 1920 - 28 hrudnia1920), Tsentralnyi derzhavnyi arkhiv hromadskykh obiednan Ukrainy, f. 269, op. 1, spr. 61.

Lystuvannia Prezydenta Ukrainskoi natsionalnoi rady [...] pro mizhnarodne vyznannia i zakhyst suverenitetu Zakhidnoukrainskoi Narodnoi Respubliky, zasudzhennia polskoi polityky v Zakhidnii Ukraini ta z inshykh pytan (1 sichnia 1921 - 21 hrudnia 1921), Tsentralnyi derzhavnyi arkhiv hromadskykh obiednan Ukrainy, f. 269, op. 1, spr. 62.

Lystuvannia Prezydenta Ukrainskoi natsionalnoi rady [...] pro mizhnarodne vyznannia i zakhyst suverenitetu Zakhidnoukrainskoi Narodnoi Respubliky, zasudzhennia polskoi polityky v Zakhidnii Ukraini ta z inshykh (14 liutoho 1922 - 30 hrudnia 1922), Tsentralnyi derzhavnyi arkhiv hromadskykh obiednan Ukrainy, f. 269, op. 1, spr. 63.

Matvii Stakhiv, Zakhidnia Ukraina. Narys istorii derzhavnoho budivnytstva ta zbroinoi borotby i dyplomatychnoi oborony v 1918-1923, T. 4-6, (Skrenton: Z Drukarni Narodnoi Voli, 1958-1961).

Mykhailo Lozynskyi, Halychyna v rr. 1918-1920, (Niu York: Chervona kalyna, 1970).

Mykhailo Rudnytskyi, "Paryzh 1919. Perevazhne stanovyshche ukrainskoi delgatsii na Myrovu Konferentsiiu", Dyplomatiia Ukrainskoi Narodnoi Respubliky v dokumentakh ta spohadakh suchasnykiv: $u$ dvokh tomakh, uporiad. i peredm. I.M. Hnatyshyna ta in. (Kyiv: Ukrainskyi pysmennyk, 2008). 
ISSN 2078-6077. Наукові зошити історичного факультету Львівського університету. 2018-2019. Випуск 19-20. Proceedings of History Faculty of Lviv University. 2018-2019. Issue 19-20.

Mykola Lytvyn, Ukrainsko-polska viina 1918-1919 rr., (Lviv: Instytut ukrainoznavstva im. I. Krypiakevycha Natsionalnoi akademii nauk Ukrainy: Instytut Tsentralno-Skhidnoi Yevropy, 1998).

"Nota Deliegatsii Skhidnoi Halychyny do Soiuzu Narodiv", Ukrainskyi prapor, ch. 61, (1920).

Oleh Pavlyshyn, Yevhen Petrushevych (1863-1940): iliustrovanyi biohrafichnyi narys, (Lviv: Manuskrypt-Lviv, 2013).

Oleh Yehreshii, "Hreko-katolytske dukhivnytstvo v umovakh Zakhidnoukrainskoi Narodnoi Respubliky: rol u formuvanni orhaniv vlady, tvorenni ukrainskoho viiska", Ukraina: kulturna spadshchyna, natsionalna svidomist, derzhavnist: zbirnyk naukovykh prats, Vyp. 18, (2009).

Pavlo Hai-Nyzhnyk, "Dmytro Vitovskyi: vstanovlennia istorychnoi daty ta obstavyn zahybeli", Viiskovo-istorychnyi almanakh, No. 1, (2010).

Polevi dukhovnyky Ukrainskoi Halytskoi Armii: u 45-richchia uchasty u vyzvolnykh zmahanniakh: (materiialy do istorii), vydav Ivan Lebedovych, (Vinnipeg: Vydav o. I. Lebedovych, 1963).

Protokoly zasidannia zizdu zakordonnykh chleniv partii sotsialistiv-federalistiv [...] ta informatsiini vidomosti vid posolstva $\mathrm{v}$ Paryzhi pro diialnist natsionalnoho ukrainskoho komitetu v Paryzhi [...], Tsentralnyi derzhavnyi arkhiv vyshchykh orhaniv vlady ta upravlinnia Ukrainy, f. 3696, op. 2, spr. 332.

Tyshkevych Mykhailo (1857-1930), hraf, dyplomat i politychnyi diiach Ukrainskoi Narodnoi Respubliky, publitsyst, istoryk, metsenat, Tsentralnyi derzhavnyi istorychnyi arkhiv Ukrainy, m. Lviv, f. 681, op. 1, spr. 1.

"Vazhni pereminy v Paryzhi", Ukrainskyi prapor, ch. 38, (1919).

Visnyk Derzhavnykh zakoniv Ukrainskoi Narodnoi Respubliky, [...] perepyska z Dyrektoriieiu, Ministerstvom zakordonnykh sprav i Derzhavnym sekretariiatom Ukrainskoi Narodnoi Respubliky, Ukrainska Biblioteka im. Symona Petliury v Paryzhi, fond 4, techka 1, dok. ch. 158. 